\title{
Anaerobic membrane reactor: Biomethane from chicken manure and high-quality effluent
}

\author{
Cynara Juliana Busato ${ }^{a,}{ }^{*}$, Cinzia Da Ros ${ }^{b}$, Roberto Pellay ${ }^{c}$, Paola Barbierato ${ }^{c}$, \\ Paolo Pavan ${ }^{a}$ \\ a Department of Environmental Sciences, Informatics and Statistics, University Ca' Foscari of Venice, via Torino 155, 30170, Mestre, VE, Italy \\ ${ }^{\mathrm{b}}$ Department of Biotechnology, University of Verona, Strada Le Grazie 15, 37100, Verona, VR, Italy

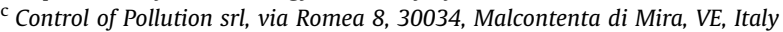

\section{A R T I C L E I N F O}

\section{Article history:}

Received 4 December 2018

Received in revised form

13 July 2019

Accepted 16 July 2019

Available online 17 July 2019

\section{Keywords:}

Anaerobic membrane bioreactor

Chicken manure

Ammonia removal

\begin{abstract}
A B S T R A C T
Chicken manure was treated in a pilot scale reactor anaerobic membrane bioreactor constituted by a completely mixed reactor combined with an ultrafiltration tube-shaped membrane in a side-stream configuration. The process operated under mesophilic condition and the inhibition of high concentration of ammonia was avoided using an ammonia stripping system. The experimental plan included a preliminary evaluation, where organic loading rates between 1.0 and $7.6 \mathrm{kgVS} / \mathrm{m} 3 /$ day were tested. The organic load higher than $4 \mathrm{kgVS} / \mathrm{m} 3 / \mathrm{d}$ caused the accumulation of volatile fatty acids and process instability. Application of the ammonia stripping was also evaluated. The best performances were achieved using a retention time of 21 days, an organic load between 1.4 and $2.0 \mathrm{kgVS} / \mathrm{m} 3 / \mathrm{d}$, and the recirculation of stripped permeate. Reduction of the ammonia permeate content by $90 \%$ through stripping and utilization of a mixture of chicken manure/water/permeate in a ratio of $0.22 / 0.72 / 0.72 \mathrm{w} / \mathrm{w}$ led to a specific biogas production of $0.59 \mathrm{~m} 3$ biogas $/ \mathrm{kgVS}$ and methane content of $66-69 \%$. The ammonia thus removed can be recovered by sulphuric acid treatment as ammonium sulphate, which can be used as a fertilizer. The proposed configuration allowed satisfactory biogas production with appropriate methane percentages, recovery of ammonium sulphate, and a high-quality effluent.
\end{abstract}

() 2019 Published by Elsevier Ltd.

\section{Introduction}

The membrane bioreactor concept (MBR) combines a biological process (aerobic or anaerobic) with the benefits of membrane separation technique. The presence of the micro- or ultrafiltration membrane leads to significant improvements and advantages [1]. The recent development of the MBR technology is mainly due to the limited availability of building area for the construction of new wastewater treatment systems. Another important factor in the development of this technology is the latest stringent regulations imposed for environmental discharge worldwide, the reduction in membrane cost, the continuous improvement in process design, and requirements of high-quality water reuse applications [2]. The anaerobic membrane bioreactor (AnMBR) is a consolidated technology for the wastewater management and treatment [3,4]. Several studies for urban and industrial wastewater treatment have

\footnotetext{
* Corresponding author.

E-mail address: juliana.busato@unive.it (C.J. Busato).
}

already been carried out, showing significant efficiency improvements compared to conventional activated sludge treatment [5].

Globally, the livestock farms produce manure accounting for 20 million tons of dry matter and 10 million tons of organic matter per day. Anaerobic digestion (AD) is a degradation process that can contribute to improve manure management and to recover energy [6]. Anaerobic conversion of chicken manure (CM) into biogas has become increasingly attractive in the recent decades as a good choice to minimize waste accumulation and recover bioenergy [7-9].

CM has a volatile solid (VS) content of $60-85 \%$ (on dry basis), which is highly degradable and can be used as a substrate to produce biogas through anaerobic digestion technology [10]. However, $\mathrm{CM}$ contains nitrogen in high concentrations due to the presence of uric acid and undigested proteins, and their microbial decomposition results in the formation and probable accumulation of toxic amounts of ammonia [11]. The total ammonia content includes the ionized form of ammonium ion $\left(\mathrm{NH}_{4}^{+}\right)$and the free, unionized gaseous form of ammonia $\left(\mathrm{NH}_{3}\right)$. The amount of $\mathrm{NH}_{3}$ depends on 
$\mathrm{pH}$, temperature, and total ammonia content, and its excess concentration has been considered as the major cause of microbial consortia inhibition over the course of anaerobic digestion of nitrogen-rich substrates [12,13].

There are several methods to avoid the ammonia inhibition process during the AD of nitrogen-rich organic wastes [14], such as dilution of chicken manure with water [15,16], co-digestion with some other livestock manure [17,18], membrane extraction [19], and acclimatization of microorganisms with high levels of ammonia [20]. Several alternative methods to deal with ammonia inhibition exist, which can be grouped into removal methods and recovery methods. Removal methods include biological treatments [21], and recovery methods comprise stripping [22], precipitation of struvite [23], and composting [24].

In the present study, we considered an AnMBR in single-stage mono-digestion for the treatment of $\mathrm{CM}$ from egg-laying hens, whose waste is characterized by a high and easily biodegradable amount of organic matter and nutrients such as nitrogen, phosphorus, and potassium. To avoid $\mathrm{NH}_{3}$ accumulation, the liquid phase was subjected to air stripping and was later recirculated. Nitrogen was recovered by implementing chemical treatment with sulphuric acid, leading to the formation of ammonium sulphate that could be utilized as a fertilizer. The liquid obtained at the end of the process can be discharged or reused for the dissolution of the feeding mix or used in irrigation, while the excess biological sludge can be used as a traditional agricultural fertilizer.

The novelty is the integration of various processes as shown in Fig. 1.

In the proposed configuration, the traditional anaerobic digester was replaced by a more efficient anaerobic membrane bioreactor, which produced less digestate and allowed the production of biogas with higher methane concentrations. The low nitrogen and carbon contents and the absence of suspended solids could simplify the treatment of the final effluent. The data obtained confirmed that the application of the MBR technology leads to a significant reduction in the environmental footprint of the overall treatment system, achieving both disinfection and a high-quality effluent.

\section{Materials and methods}

\subsection{Analytical methods and stability parameters}

The inoculum and substrate were characterized considering the parameters such as total solids (TS), total volatile solids (VS), chemical oxygen demand on soluble and dried fractions (sCOD and $\mathrm{COD})$, biochemical oxygen demand $\left(\mathrm{BOD}_{5}\right)$, total Kjeldahl nitrogen (TKN), ammonium content $\left(\mathrm{N}-\mathrm{NH}_{4}^{+}\right), \mathrm{pH}$, and total phosphorus content $\left(\mathrm{P}_{\text {tot }}\right)$ according to the standard methods [25].

During the AnMBR operation, analyses of $\mathrm{pH}$, alkalinity, and volatile fatty acids (VFA) were performed daily on digestate samples, while TS, VS, COD and $\mathrm{N}-\mathrm{NH}_{4}^{+}$content were monitored thrice a week. Finally, TKN and $P_{\text {tot }}$ were determined once a week. The alkalinity was determined using end-points $\mathrm{pH}$ values of 4 and 6

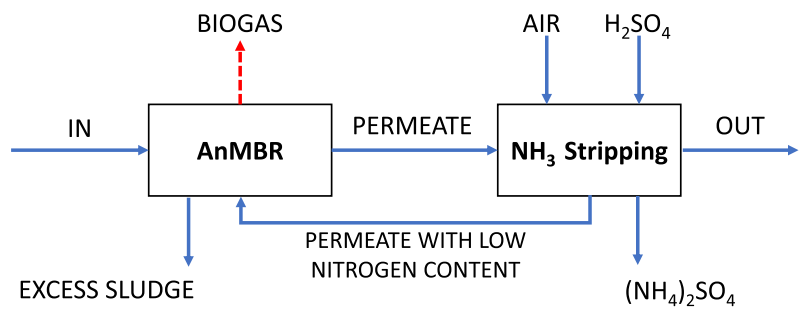

Fig. 1. MBR technology process. and the results were reported as $\mathrm{mgCaCO}_{3} / \mathrm{L}$ [25].

The analysis of VFA was conducted using an Agilent $6890 \mathrm{~N}$ gas chromatograph, equipped with an Agilent J\&W DB-WAXetr column (30 $\mathrm{m} \times 0.530 \mathrm{~mm} \times 1.0 \mu \mathrm{m}$ thickness) and a flame ionisation detector $\left(\mathrm{T}=250^{\circ} \mathrm{C}\right)$ with hydrogen as the carrier gas. The analyses were conducted using a ramp temperature program from 120 to $200^{\circ} \mathrm{C}$. The samples were centrifuged and filtered with a $0.2 \mu \mathrm{m}$ filter before the analysis. The biogas production was monitored using a flow metre (Ritter Company ${ }^{\mathrm{TM}}$, www.ritter.de/en/products/ drum-type-gas-meters), and the biogas composition was determined once a day using a portable infrared gas analyser (Optima 7 biogas-MRU).

\subsection{Experimental setup}

\subsubsection{Description of the pilot scale reactor}

During the trials, a pilot scale reactor with $0.03 \mathrm{~m}^{3}$ of working volume was used, along with a mechanical mixing system. A constant temperature was maintained using an external resistance jacket, digitally controlled by a thermocouple positioned inside the digester. AnMBR was coupled with a tube-shaped, external membrane unit made of $0.1 \mu \mathrm{m}$ polyvinylidene fluoride (PCI Membranes Ultrafiltration; Figs. 2 and 3).

\subsubsection{Anaerobic digestion}

The experimental plan included inoculum and substrate characterization followed by the AnMBR operation. The reactor was inoculated with the digestate from another pilot scale digester and the biomass was acclimatized by maintaining the system at $37^{\circ} \mathrm{C}$. Once the biomass was active and responded with the production of biogas, then the reactor was fed daily.

The experimentation included four periods as reported in Table 1 where the operating conditions adopted during the entire experimental set-up are shown. The preliminary trial was carried out by increasing the organic loading rate (OLR) from 1.0 to 7.6 $\mathrm{kgVS} / \mathrm{m}^{3} / \mathrm{d}$ to study the maximum load supported by the system. Once the optimal load conditions were identified, three operating conditions were tested based on the results obtained by monitoring the conditions for process stability.

\subsubsection{Ammonium air stripping}

The stripping process was applied in the main trials when permeate was recirculated in the AnMBR and it was carried out once a week at $50^{\circ} \mathrm{C}$, with $\mathrm{NaOH}$ added to achieve a pH equal to 9.5 in a $30 \mathrm{~L}$ tank as reactor. During the process, free ammonia was removed from the liquid using air flow, and subsequently trapped by excess sulphuric acid solution. Samples were collected from the reactor at each hour during the process and the $\mathrm{N}-\mathrm{NH}_{4}^{+}$concentration and the $\mathrm{pH}$ were measured. The ammonium stripping reactor feedstock consisted of the liquid phase digestate.

\section{Results and discussion}

\subsection{Substrate characterization}

Chicken manure was collected in four local egg-laying hen farms identified as CM1, CM2, CM3 and CM4. The substrates were analysed and their characteristics are shown in Table 2.

Samples of CM2 and CM3 were collected once and analysed in triplicate. Instead CM1 was collected twice during the summer (CM1A and CM1B). CM4 samples were collected along all the year: $\mathrm{CM} 4 \mathrm{~A}$ during the autumn, CM4B during the spring, CM4C during the summer and finally CM4D during the winter.

Samples showed a relative variability that depends on the species, diet, and seasonality, as seen from Fig. 4a-b. However, they 


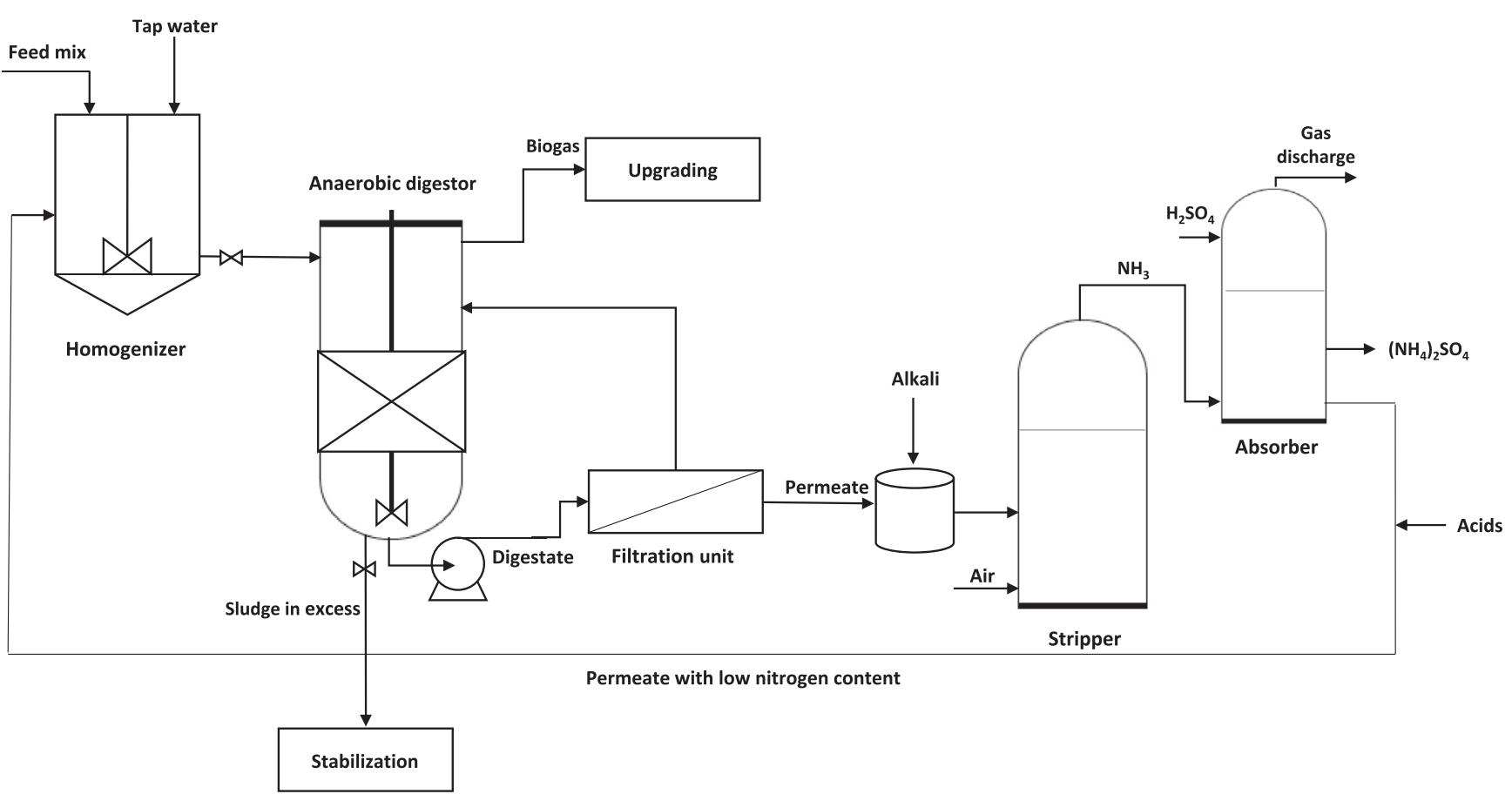

Fig. 2. Flow chart of the process.

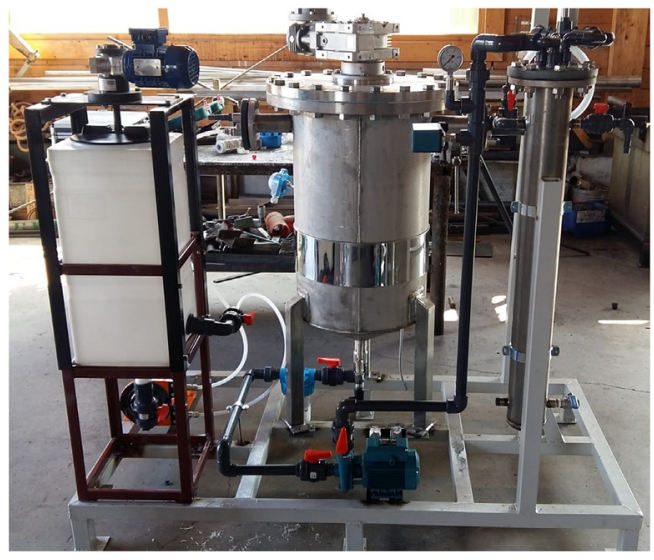

Fig. 3. Pilot scale anaerobic membrane bioreactor.

appeared to be in relatively good agreement with the data found in literature [26].

Literature data*: TS: 467-688 g/kg; VS: 397-530 g/kg; COD: 751-1000 g/kg - *RiducaReflui Project- Nitrates from problem to resource - funded by Veneto Region (D.G.R. 4031 - 30/12/2008).

$\mathrm{CM}$ is characterized by high TS and ash content due to a diet rich in calcium carbonate, which is necessary for the production of the egg shell. The quality of the substrate depends on its intrinsic characteristics, as well as the seasonality and methods of storage. During winter, the dry matter content is usually lower due to reduced ventilation and lower temperatures. Prolonged storage in mounds determines the occurrence of aerobic and anaerobic phenomena that progressively reduce the energy content.

The samples analysed showed $53-66 \%$ of VS content (in dry basis), which is biodegradable and can be used as a substrate for biogas production through anaerobic digestion.

Currently, $\mathrm{CM}$ is used in anaerobic digestion plant stowing to its advantageous characteristics, such as high dry matter content that reduces transport cost and digestate volume, good specific yield in terms of quantity and quality of biogas, presence of essential mineral elements for the biochemical reactions of microbial flora, and good buffer capacity due to the high alkalinity.

Nitrogen appears to be the critical element characterizing this substrate. Therefore, the use of $\mathrm{CM}$ as substrate for anaerobic digestion must be carefully evaluated because of the high nitrogen content and the high amounts of sediment in the digester due to calcium carbonate. On the one hand, the high content of nitrogen and carbonates requires careful control of the quantities introduced, while on the other hand, it gives the poultry manure a good buffer capacity, which is useful for the stability of the process. In order to monitor the system, high-frequency analysis of stability parameters such as alkalinity, pH, VFA, and ammonium content must be conducted.

Table 1

Operating conditions during the experimental set-up.

\begin{tabular}{|c|c|c|c|c|}
\hline \multirow{2}{*}{\multicolumn{2}{|c|}{ Run }} & \multirow{3}{*}{$\frac{\mathrm{HRT}}{\mathrm{d}}$} & \multirow{3}{*}{$\frac{\frac{\mathrm{OLR}}{\mathrm{kgVS} / \mathrm{m}^{3} / \mathrm{d}}}{1.0-7.6}$} & \multirow{3}{*}{$\begin{array}{l}\frac{\text { FEED MIX }}{(\mathrm{w} / \mathrm{w})} \\
0.22 / 0.78(\mathrm{CM} / \text { water })\end{array}$} \\
\hline & & & & \\
\hline \multicolumn{2}{|c|}{ Preliminary trial } & & & \\
\hline \multirow[t]{3}{*}{ Main trials } & Start-up 1 & $17-30$ & $1.3-2.4$ & $0.22 / 0.78(\mathrm{CM} /$ water $)$ \\
\hline & Start-up 2 & $20-49$ & $1.1-2.0$ & from $0.22 / 0.39 / 0.39$ to $0.22 / 0.78 / 1.5(\mathrm{CM} /$ water/permeate) \\
\hline & Start-up 3 & 21 & $1.4-2.0$ & $0.22 / 0.72 / 0.72(\mathrm{CM} /$ water/permeate $)$ \\
\hline
\end{tabular}


Table 2

Chemical-physical characteristics of chicken manure analysed in triplicate (average value \pm standard deviation).

\begin{tabular}{|c|c|c|c|c|}
\hline Parameter & CM1 & CM2 & CM3 & CM4 \\
\hline TS (gTS/kg) & $289 \pm 13$ & $453 \pm 47$ & $434 \pm 33$ & $385 \pm 94$ \\
\hline VS (gVS/kg) & $153 \pm 33$ & $301 \pm 26$ & $231 \pm 7$ & $241 \pm 53$ \\
\hline VS/TS (\%) & 53 & 66 & 53 & 63 \\
\hline Ash (\%) & $47 \pm 10$ & $33 \pm 3$ & $47 \pm 3$ & $37 \pm 5$ \\
\hline $\mathrm{sCOD}\left(\mathrm{mgO}_{2} / \mathrm{L}\right)$ & $13,467 \pm 1730$ & $18,993 \pm 935$ & $13,835 \pm 3783$ & $11,085 \pm 4766$ \\
\hline $\mathrm{COD}\left(\mathrm{mgO}_{2} / \mathrm{gTS}\right)$ & $663 \pm 93$ & $605 \pm 71$ & $500 \pm 31$ & $697 \pm 84$ \\
\hline $\mathrm{BOD}_{5}\left(\mathrm{mgO}_{2} / \mathrm{L}\right)$ & $10,527 \pm 2753$ & $11,329 \pm 1077$ & $5290 \pm 1058$ & $7461 \pm 459$ \\
\hline TKN (mgN/gTS) & $23.0 \pm 6.6$ & - & - & $19.0 \pm 5.1$ \\
\hline $\mathrm{N}-\mathrm{NH}_{4}^{+}(\mathrm{mg} / \mathrm{L})$ & $1881 \pm 110$ & $2643 \pm 729$ & $1010 \pm 157$ & $1515 \pm 544$ \\
\hline $\mathrm{pH}$ & $7.8 \pm 0.9$ & $7.7 \pm 0.4$ & $8.4 \pm 0.1$ & $7.6 \pm 8.2$ \\
\hline Ptot (gP/kgTS) & $21.3 \pm 4.9$ & $16.6 \pm 1.0$ & $34.2 \pm 4.0$ & $24.7 \pm 3.1$ \\
\hline
\end{tabular}

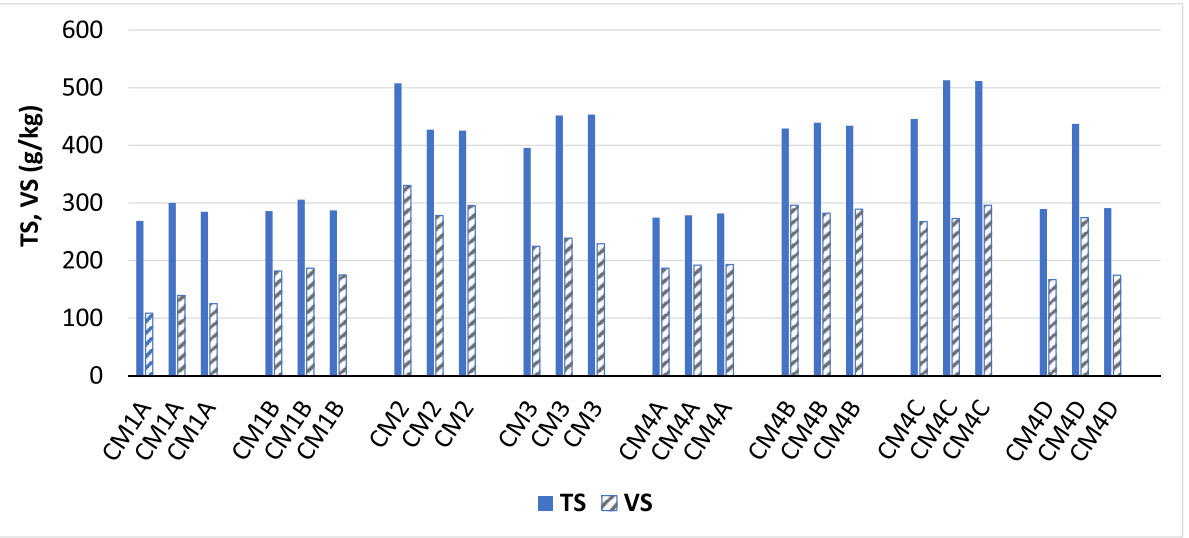

A

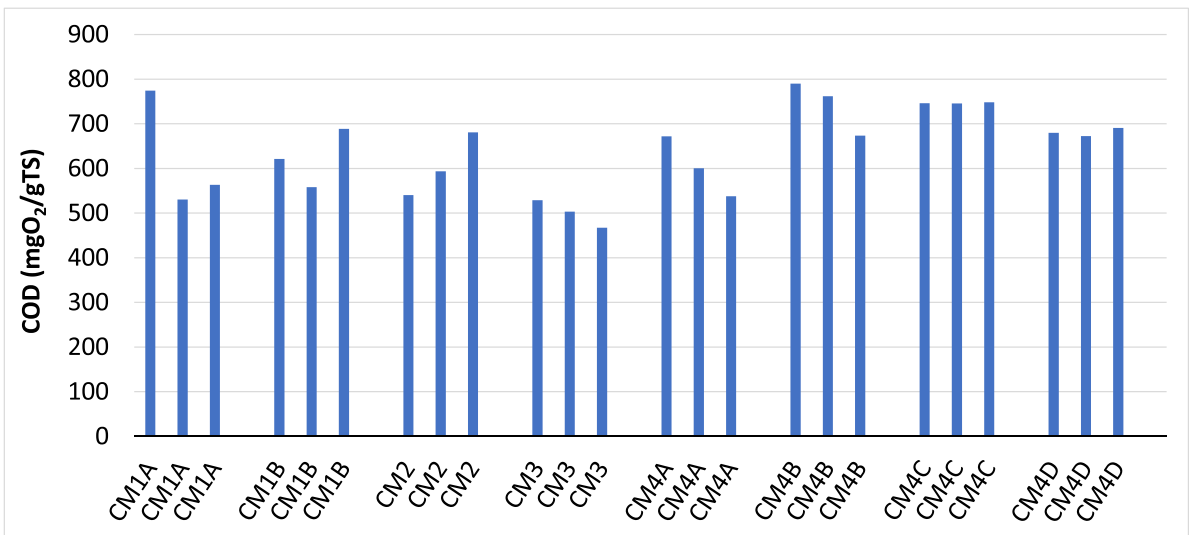

B

Fig. 4. Chicken manure characteristics: a) TS and VS content, b) COD content.

Alternatively, technologies for reducing the concentration of ammonium content can be coupled to the AD plants, in the recirculated digestate or in the post-digestion treatment lines.

\subsection{Preliminary trial}

The inoculum was collected from a pilot scale anaerobic digestor and analysed. The solid content was $22.5 \mathrm{gTS} / \mathrm{kg}$ with $47 \%$ constituted by volatile fraction. The COD concentration was $344 \mathrm{mgO}_{2} /$ gTS. The $\mathrm{pH}$ was 9.1 due to the high ammonium content (2550 $\left.\mathrm{mgN}^{-\mathrm{NH}_{4}^{+}} / \mathrm{L}\right)$.

During the preliminary trial, the reactor was maintained under mesophilic conditions $\left(37 \pm 2{ }^{\circ} \mathrm{C}\right)$ and was fed daily with $\mathrm{CM} 4$ mixed with tap water in a ratio of $0.22 / 0.78 \mathrm{w} / \mathrm{w}$. CM requires pretreatment to remove feathers, sand, and pebbles to preserve the membrane. Samples of pre-treated CM were analysed periodically, and their characteristics are shown in Table 3.

Based on the characteristics of the substrate, as shown in Fig. 5, the CM had variable TS and VS contents after pre-treatment. The average percentage ratio between VS and TS was $52 \%$, which suggests a reasonable potential of biogas production.

Table 4 shows the main chemico-physical characteristics of the digestate, stability parameters, and production yields during the preliminary phase. 
Table 3

Chemical-physical characteristics of pre-treated CM4 during the preliminary trial.

\begin{tabular}{llll}
\hline Parameter & Units & Average value \pm Standard deviation & Min-Max \\
\hline TS & gTS $/ \mathrm{kg}$ & $373 \pm 61$ & $289-513$ \\
VS & $\mathrm{gVS} / \mathrm{kg}$ & $193 \pm 56$ & $111-301$ \\
VS/TS & $\%$ & $52 \pm 11$ & $28-69$ \\
$\mathrm{COD}$ & $\mathrm{mgO}_{2} / \mathrm{gTS}$ & $577 \pm 134$ & $368-878$ \\
TKN & $\mathrm{mgN}^{-N_{4}}+\mathrm{gTS}$ & $19 \pm 5$ & $12-30$ \\
$\mathrm{P}_{\text {tot }}$ & $\mathrm{mgP} / \mathrm{gTS}$ & $30 \pm 9$ & $17-46$ \\
\hline
\end{tabular}

The OLR was progressively increased from 1.0 to $7.6 \mathrm{kgVS} / \mathrm{m}^{3}$ / day over a period of 100 days and subsequently reduced gradually to study the maximum load supported by the system (Fig. 6). The stability parameters of the trophic chain were carefully monitored during this phase of verification of the maximum load conditions, particular attention was paid to VFA content. Fig. 6 shows the progress of OLR load and the corresponding increase of VFA concentration in the digestate.

The VFA content was comparatively low at approximately $3 \mathrm{~g} / \mathrm{L}$ when the OLR was maintained at $3-4 \mathrm{kgVS} / \mathrm{m}^{3} / \mathrm{d}$, in the initial conditions following the start-up (days 40-70). At day 70 the OLR increased to $>7 \mathrm{kgVS} / \mathrm{m}^{3} / \mathrm{d}$ and VFA concentration rose progressively up to value above $10 \mathrm{~g} / \mathrm{L}$ at day 100 . The OLR was reduced to previous condition from day 120 but the VFA accumulation, created under overload conditions, cannot be compensated by the system, even over a long period.

Fig. 7 shows the trends of $\mathrm{pH}$ and partial and total alkalinity. The $\mathrm{pH}$ ranged between 7.93 and 8.85 . The partial alkalinity $(\mathrm{pH} 6)$ ranged from 3.29 to $9.08 \mathrm{gCaCO}_{3} / \mathrm{L}$, while the total alkalinity ( $\mathrm{pH} 4$ ) showed higher values of $6.44-15.04 \mathrm{gCaCO}_{3} / \mathrm{L}$. Notice that the highest applied OLR corresponded with $\mathrm{pH}$ drop and significant reduction of alkalinity confirming the process instability. A load interval of $3-4 \mathrm{kgVS} / \mathrm{m}^{3} / \mathrm{d}$ can be considered optimal for a stable process fed by chicken manure.

During the trial, the percentage of methane present in the biogas was also monitored. Values between 60 and 70\% were observed, with an average value of $62 \%$ in the period between days 27 and 157 (Fig. 8). The initial start-up and the last 30 days of the operation were an exception, where the percentage detected is substantially incompatible with the actual development of the process. It remains to be clarified whether the decrease recorded at the end of the test could be attributed to the previous overload conditions of the system or it was caused by other factors. The average value for specific gas production (SGP) was $0.33 \mathrm{~m}^{3}$ biogas $/$ $\mathrm{kgVS}$. Although it was not high, it agrees with this matrix, which obviously suffered from the problems associated with the massive presence of nitrogen compounds.

\subsection{Main trial under pseudo-stationary conditions}

After the preliminary tests, three operational conditions were tested. The most significant difference between the three conditions was that the first condition was tested without the stripping process of ammonia and the recirculation of the permeate, while the second and third conditions were tested with this approach. In particular, during the third trial, HRT was maintained constant.

The first trial was related to the period between days 1 and 60,

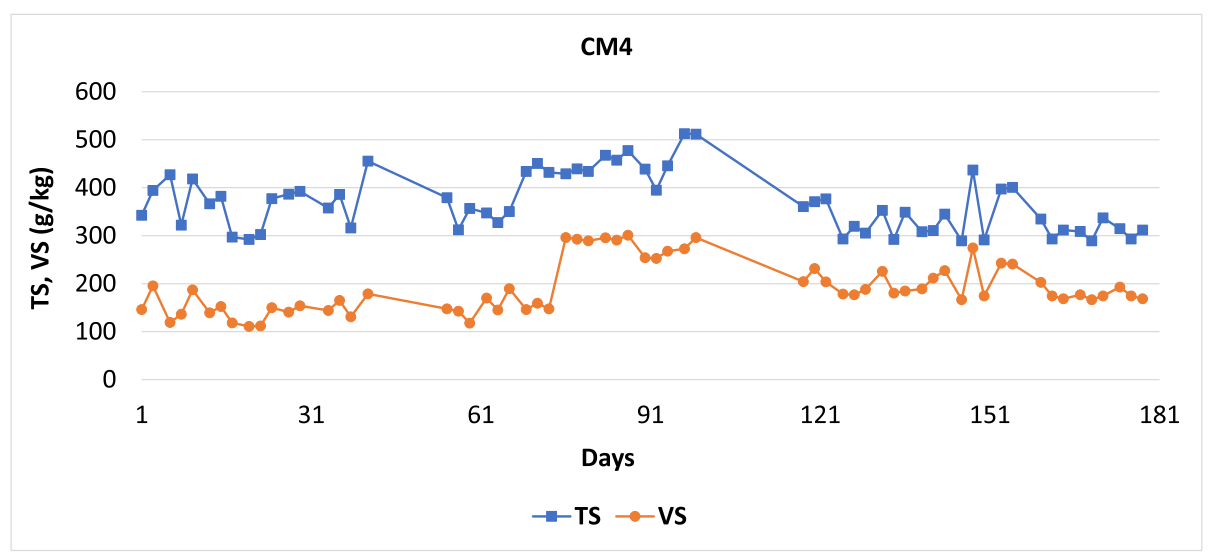

Fig. 5. Total solids (TS) and volatile solids (VS) in CM4 during the preliminary trial.

Table 4

Chemical-physical characteristics of the digestate, stability parameters, and production yields during the preliminary trial.

\begin{tabular}{|c|c|c|c|}
\hline Parameter & Units & Average value \pm Standard deviation & Min-Max \\
\hline TS & $\mathrm{gTS} / \mathrm{kg}$ & $108 \pm 33$ & $65-169$ \\
\hline VS & $\mathrm{gVS} / \mathrm{kg}$ & $47 \pm 11$ & $26-66$ \\
\hline VS/TS & $\%$ & $45 \pm 6$ & $34-57$ \\
\hline sCOD & $\mathrm{mgO}_{2} / \mathrm{L}$ & $11,701 \pm 3427$ & $6857-21,500$ \\
\hline TKN & $\mathrm{mgN}-\mathrm{NH}_{4}^{+} / \mathrm{L}$ & $2597 \pm 518$ & $1530-3797$ \\
\hline$P_{\text {tot }}$ & $\mathrm{mgP} / \mathrm{L}$ & $73 \pm 60$ & $5-176$ \\
\hline $\mathrm{pH}$ & - & $8.30 \pm 0.20$ & $7.93-8.85$ \\
\hline P. alkalinity & $\mathrm{gCaCO}_{3} / \mathrm{L}$ & $6.40 \pm 1.38$ & $3.29-9.08$ \\
\hline T. alkalinity & $\mathrm{gCaCO}_{3} / \mathrm{L}$ & $11.74 \pm 2.09$ & $6.44-15.04$ \\
\hline VFA & $\mathrm{gCOD} / \mathrm{L}$ & $7.96 \pm 5.11$ & $1.06-19.95$ \\
\hline $\mathrm{N}-\mathrm{NH}_{4}^{+}$ & $\mathrm{mgN} / \mathrm{L}$ & $2208 \pm 376$ & $1430-2980$ \\
\hline SGP & $\mathrm{m}_{\text {biogas }}^{3} / \mathrm{kgVS}$ & $0.33 \pm 0.12$ & $0.13-0.64$ \\
\hline GPR & $\mathrm{m}_{\text {biogas }}^{3} / \mathrm{m}^{3} \mathrm{~d}$ & $1.30 \pm 0.86$ & $0.15-3.53$ \\
\hline $\mathrm{CH}_{4}$ & $\%$ & $54 \pm 17$ & $5.0-72$ \\
\hline
\end{tabular}




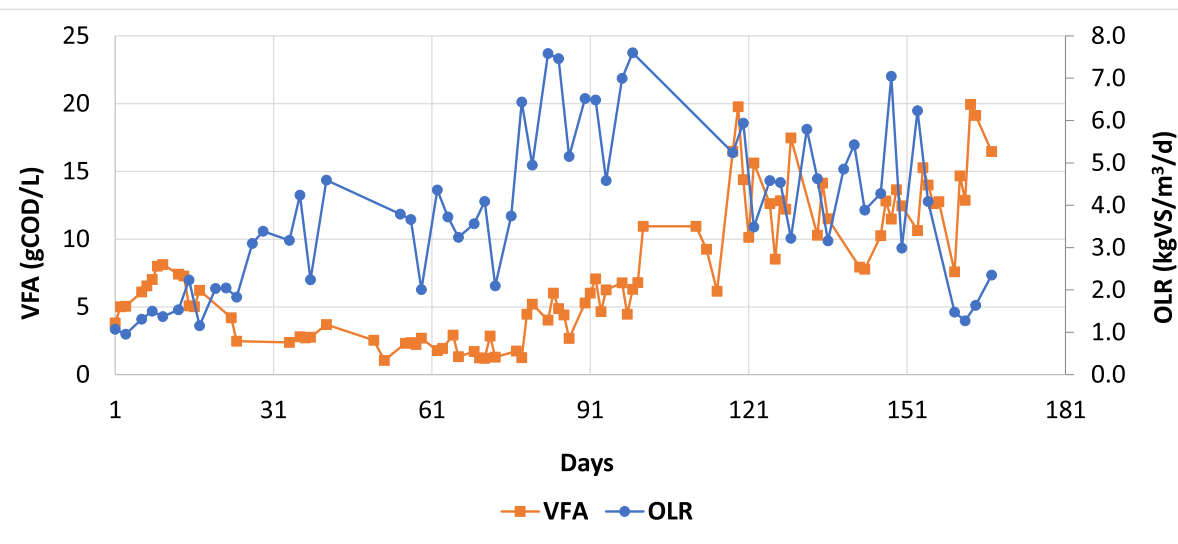

Fig. 6. Organic loading rate (OLR) and volatile fatty acids (VFA) content during the preliminary trial.

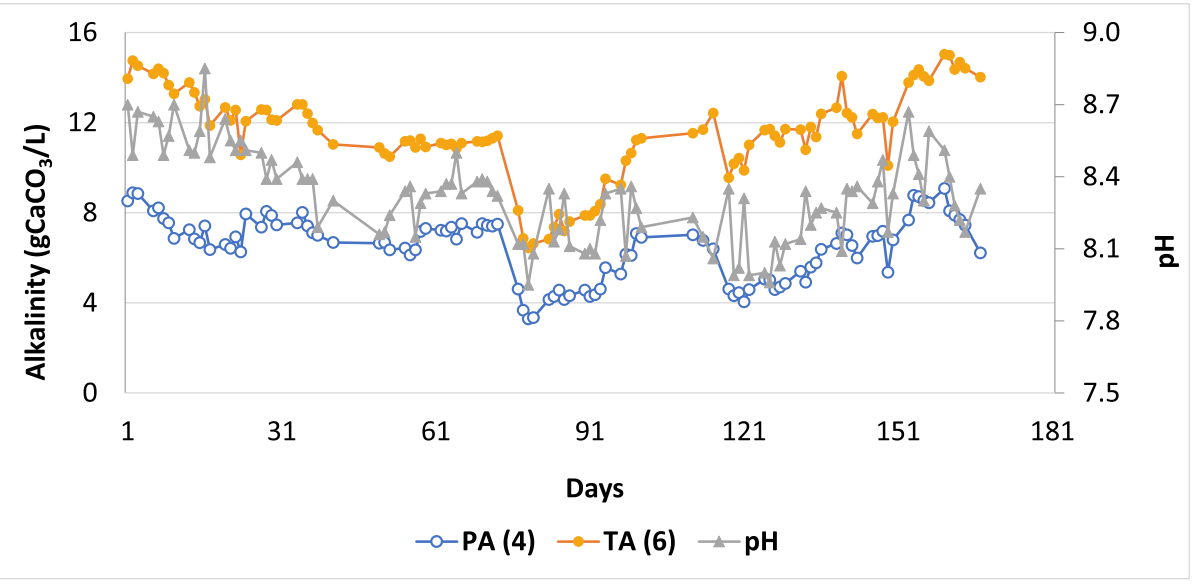

Fig. 7. Partial alkalinity (PA), total alkalinity (TA), and pH during the preliminary trial.

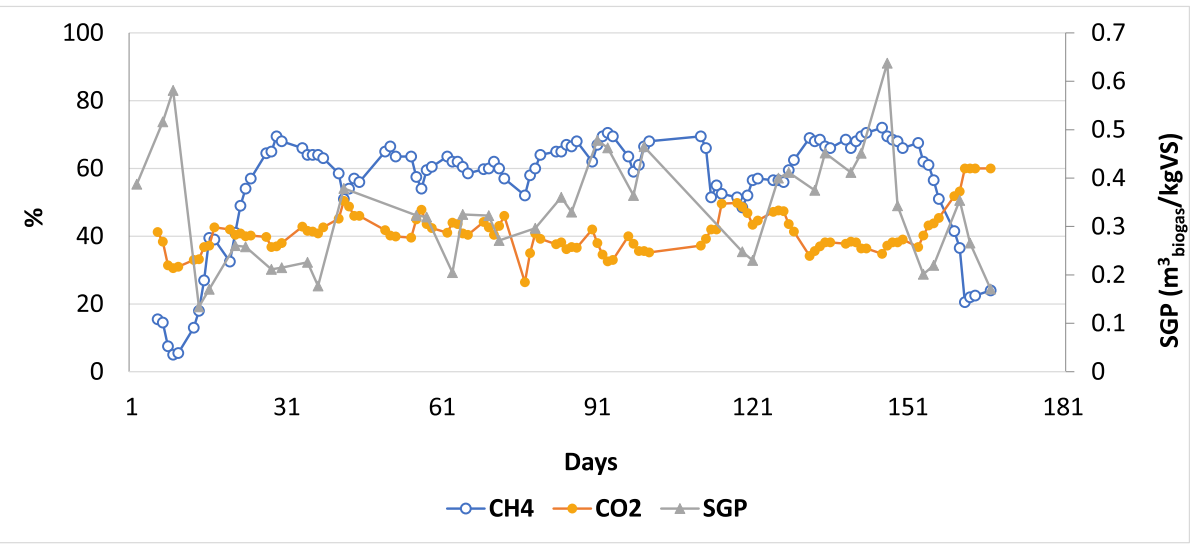

Fig. 8. Biogas composition (\% $\mathrm{CO} 2$ and $\% \mathrm{CH} 4)$ and specific gas production (SGP) during preliminary trial.

including the start-up phase when the biomass was acclimatized. Subsequently, the reactor was fed with a mixture of CM4 (Table 5) and tap water in a ratio of $0.22 / 0.78$ by weight. Based on the results obtained during the preliminary tests, the OLR was increased from 1.3 to $2.4 \mathrm{kgVS} / \mathrm{m}^{3} /$ day and the HRT was between 17 and 30 days (Fig. 9). The ammonium was not stripped from the permeate and a progressive accumulation of ammonium was observed until exceeding $3 \mathrm{gN}-\mathrm{NH}_{4}^{+} / \mathrm{L}$. When this value was reached an increasing concentration of VFA was observed up to a final value above $6 \mathrm{~g} / \mathrm{L}$. On the other hand, the $\mathrm{pH}$ and alkalinity remained high as shown in Table 6. The VFA level indicated an imbalance in the trophic chain that can be ascribed to the ammonium inhibition to methanogenic bacteria. With the purpose of recover the process stability, the OLR was reduced and the biogas production dropped down (Fig. 10). The percentage of methane present in the biogas was monitored along the trial and it remained always higher than 55\%. This value 
Table 5

Chemical-physical characteristics of chicken manure during the trial period.

\begin{tabular}{|c|c|c|c|}
\hline \multicolumn{4}{|l|}{ CM1 } \\
\hline Parameter & Units & Average value \pm standard deviation & Min-Max \\
\hline TS & $\mathrm{gTS} / \mathrm{kg}$ & $278 \pm 23$ & $237-320$ \\
\hline VS & $\mathrm{gVS} / \mathrm{kg}$ & $149 \pm 15$ & $126-176$ \\
\hline VS/TS & $\%$ & $54 \pm 3$ & $48-58$ \\
\hline COD & $\mathrm{mgO}_{2} / \mathrm{gTS}$ & $598 \pm 66$ & $472-785$ \\
\hline TKN & $\mathrm{mgN}^{-} \mathrm{NH}_{4}^{+} / \mathrm{gTS}$ & $19 \pm 3$ & $13-22$ \\
\hline $\mathrm{P}_{\text {tot }}$ & $\mathrm{mgP} / \mathrm{gTS}$ & $51 \pm 25$ & $30-94$ \\
\hline \multicolumn{4}{|l|}{ CM4 } \\
\hline Parameter & Units & Average value \pm standard deviation & Min-Max \\
\hline TS & $\mathrm{gTS} / \mathrm{kg}$ & $280 \pm 16$ & $253-323$ \\
\hline VS & $\mathrm{gVS} / \mathrm{kg}$ & $171 \pm 16$ & $140-211$ \\
\hline VS/TS & $\%$ & $61 \pm 4$ & $50-67$ \\
\hline COD & $\mathrm{mgO}_{2} / \mathrm{gTS}$ & $639 \pm 76$ & $502-828$ \\
\hline TKN & $\mathrm{mgN}^{-\mathrm{NH}_{4}^{+}} / \mathrm{gTS}$ & $26 \pm 7$ & $14-35$ \\
\hline $\mathrm{P}_{\text {tot }}$ & $\mathrm{mgP} / \mathrm{gTS}$ & $38 \pm 22$ & $12-101$ \\
\hline
\end{tabular}

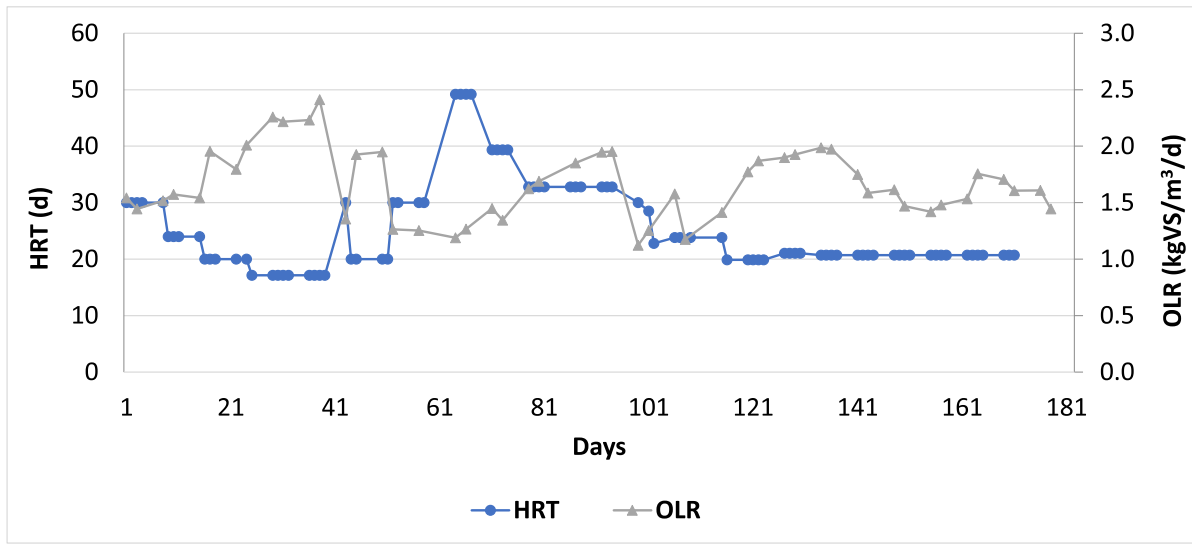

Fig. 9. Organic loading rate (OLR) and hydraulic retention time (HRT) during the trial period.

indicated that methanogenis was never completely inhibited and suggested that biogas production could be significantly improved reducing the ammonium level in the reactors. The peak of ammonium concentration corresponded to reduction of the methane content in the biogas, confirming the toxicity of ammonium to the process (Figs. 11 and 12).

During the second trial, between days 61 and 124, the substrate was replaced with CM1 that had characteristics comparable with those of CM4, as shown in Table 5. Moreover, an air stripping system was used to recover the nitrogen and reduce the toxicity caused by free ammonia. The reactor was fed daily with a mixture of CM1, tap water, and permeate after stripping in a ratio of 0.22 / $0.39 / 0.39$ by weight for five weeks. As can be seen in Fig. 11, the VFA remained below $4 \mathrm{~g} / \mathrm{L}$ but the ammonium concentration increased step by step until inhibiting values. Subsequently, the permeate and water contents in the feed mixture were increased until a ratio of $0.22 / 0.78 / 1.5$ by weight. As consequence, the feed was replaced with a more diluted mix, the OLR reduced around $1.1-1.5 \mathrm{kgVS} / \mathrm{m}^{3}$ /

Table 6

Chemical-physical characteristics of the digestate, stability parameters, and production yields during the first trial.

\begin{tabular}{|c|c|c|c|}
\hline Parameter & Units & Average value \pm standard deviation & Min-Max \\
\hline TS & gTS/kg & $75 \pm 7$ & $55-82$ \\
\hline VS & $\mathrm{gVS} / \mathrm{kg}$ & $30 \pm 4$ & $21-35$ \\
\hline VS/TS & $\%$ & $40 \pm 2$ & $38-43$ \\
\hline sCOD & $\mathrm{mgO}_{2} / \mathrm{L}$ & $6779 \pm 1415$ & $4310-9600$ \\
\hline TKN & $\mathrm{mgN}^{-\mathrm{NH}_{4}^{+}} / \mathrm{L}$ & $2906 \pm 650$ & $2145-3898$ \\
\hline $\mathrm{P}_{\text {tot }}$ & $\mathrm{mgP} / \mathrm{L}$ & $313 \pm 89$ & $179-448$ \\
\hline $\mathrm{pH}$ & - & $8.38 \pm 0.10$ & $8.17-8.62$ \\
\hline P. alkalinity & $\mathrm{gCaCO}_{3} / \mathrm{L}$ & $9.41 \pm 0.89$ & $7.58-10.82$ \\
\hline T. alkalinity & $\mathrm{gCaCO}_{3} / \mathrm{L}$ & $14.93 \pm 2.02$ & $11.87-18.04$ \\
\hline VFA & $\mathrm{gCOD} / \mathrm{L}$ & $2.68 \pm 1.82$ & $0.45-7.11$ \\
\hline $\mathrm{N}-\mathrm{NH}_{4}^{+}$ & $\mathrm{mgN} / \mathrm{L}$ & $2648 \pm 577$ & $1880-3720$ \\
\hline SGP & $\mathrm{m}_{\text {biogas }}^{3} / \mathrm{kgVS}$ & $0.44 \pm 0.08$ & $0.30-0.59$ \\
\hline GPR & $\mathrm{m}^{3}$ biogas $/ \mathrm{m}^{3} / \mathrm{d}$ & $0.80 \pm 0.18$ & $0.40-1.19$ \\
\hline $\mathrm{CH}_{4}$ & $\%$ & $68 \pm 4$ & $58-76$ \\
\hline
\end{tabular}




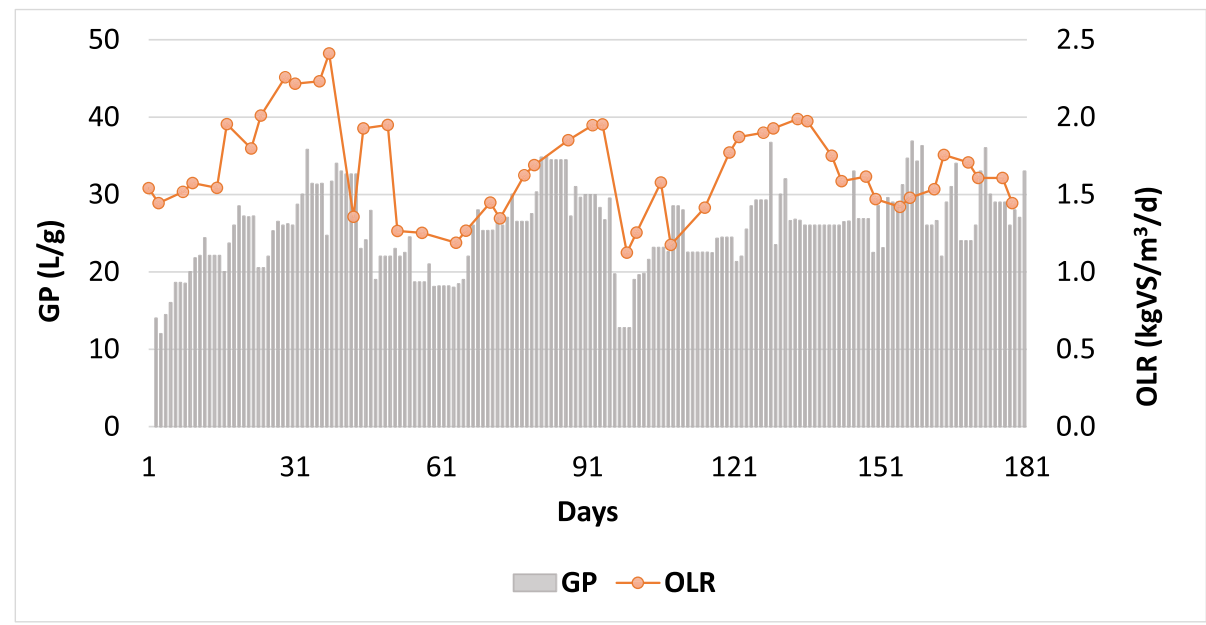

Fig. 10. Gas production (GP) and organic loading rate (OLR) during the trial.

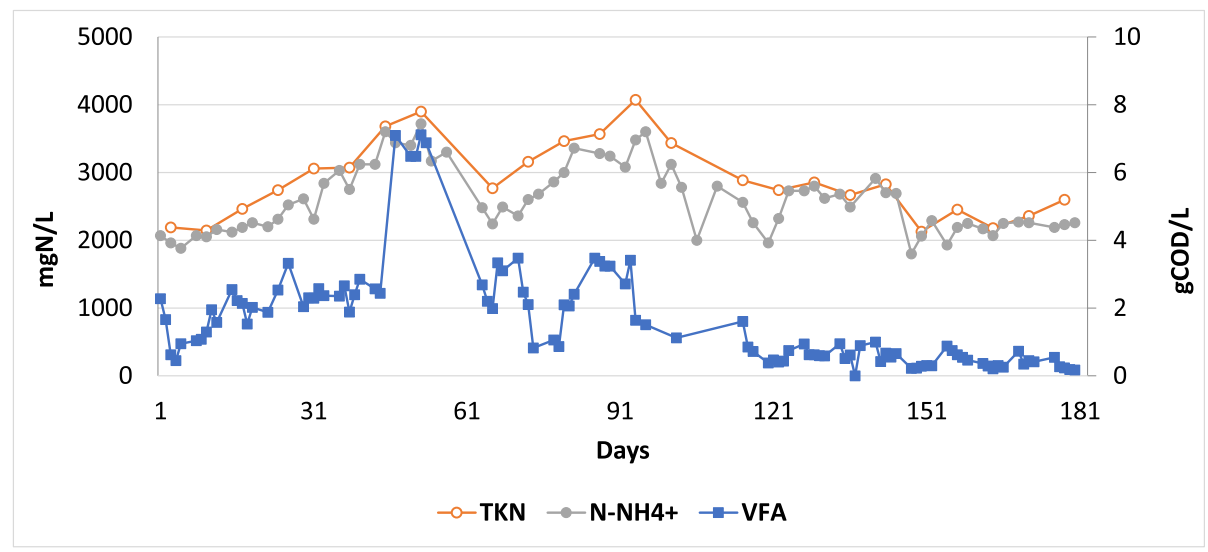

Fig. 11. Volatile fatty acids (VFA), ammonium $\left(\mathrm{N}-\mathrm{NH}_{4}^{+}\right)$and total Kjeldahl nitrogen (TKN) contents during the trial.

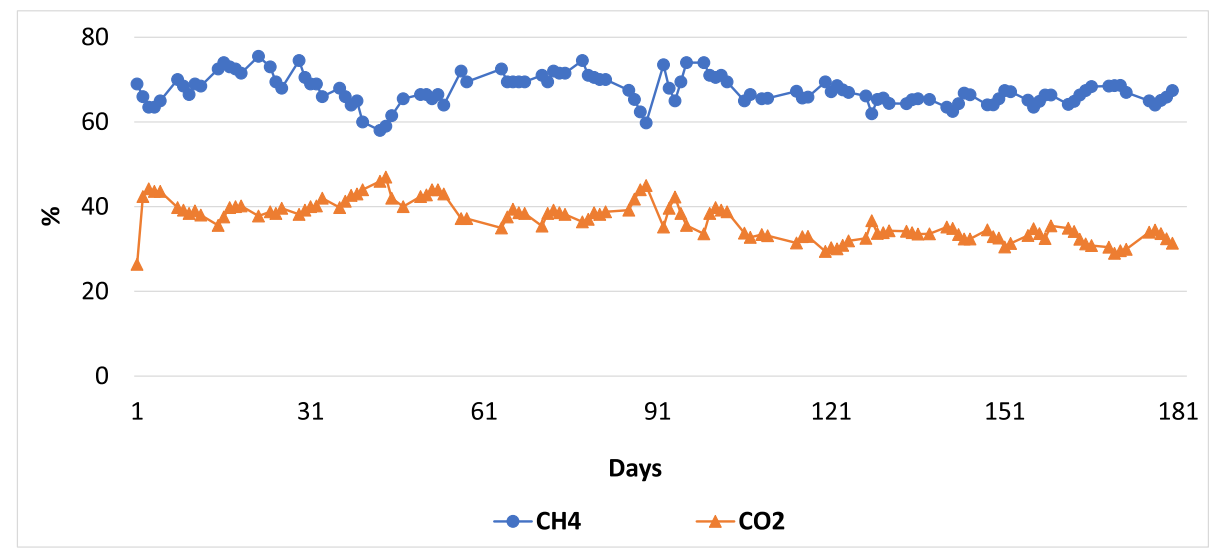

Fig. 12. Gas composition during the trial.

day, while the HRT became shorter (20-21 days, Fig. 9). Although the average parameters of digestates (Table 7) didn't change significantly from the first trial, the specific biogas production improved from 0.44 to $0.55 \mathrm{~m}^{3} / \mathrm{kgVS}$ with methane percentage around 69\%.

During the third trial, between days 125 and 181, the reactor was fed daily with a mixture of CM1, tap water and permeate after stripping in a ratio of $0.22 / 0.72 / 0.72$ by weight. The OLR was maintained between 1.4 and $2.0 \mathrm{kgVS} / \mathrm{m}^{3} /$ day, with a 21-day HRT (Fig. 9). The steady-state was achieved with an ammonium concentration of approximately $2.5 \mathrm{gN}^{-\mathrm{NH}_{4}^{+}} / \mathrm{L}$ and VFA content not exceeding the order of hundreds of ppm (Fig. 11). The average total alkalinity value was $12 \mathrm{gCaCO}_{3} / \mathrm{L}$, which was adequate for this trial. The stability of the $\mathrm{pH}$ values during this period was also worth 
Table 7

Chemical-physical characteristics of the digestate, stability parameters, and production yields during the second trial.

\begin{tabular}{|c|c|c|c|}
\hline Parameter & Units & Average value \pm standard deviation & Min-Max \\
\hline TS & gTS/kg & $70 \pm 5$ & $61-79$ \\
\hline VS & $\mathrm{gVS} / \mathrm{kg}$ & $28 \pm 2$ & $23-34$ \\
\hline VS/TS & $\%$ & $40 \pm 1$ & $38-44$ \\
\hline sCOD & $\mathrm{mgO}_{2} / \mathrm{L}$ & $4348 \pm 1310$ & $2264-6606$ \\
\hline TKN & $\mathrm{mgN}^{-\mathrm{NH}_{4}^{+}} / \mathrm{L}$ & $3261 \pm 461$ & $2739-4072$ \\
\hline$P_{\text {tot }}$ & $\mathrm{mgP} / \mathrm{L}$ & $364 \pm 106$ & $237-527$ \\
\hline $\mathrm{pH}$ & - & $8.30 \pm 0.13$ & $8.09-8.58$ \\
\hline P. alkalinity & $\mathrm{gCaCO}_{3} / \mathrm{L}$ & $8.89 \pm 1.03$ & $7.41-11.34$ \\
\hline T. alkalinity & $\mathrm{gCaCO}_{3} / \mathrm{L}$ & $13.79 \pm 1.60$ & $11.22-17.30$ \\
\hline VFA & $\mathrm{gCOD} / \mathrm{L}$ & $1.93 \pm 1.08$ & $0.38-3.47$ \\
\hline $\mathrm{N}-\mathrm{NH}_{4}^{+}$ & $\mathrm{mgN} / \mathrm{L}$ & $2755 \pm 452$ & $1960-3600$ \\
\hline SGP & $\mathrm{m}_{\text {biogas }}^{3} / \mathrm{kgVS}$ & $0.55 \pm 0.08$ & $0.40-0.69$ \\
\hline GPR & $\mathrm{m}^{3}$ biogas $/ \mathrm{m}^{3} / \mathrm{d}$ & $0.84 \pm 0.17$ & $0.43-1.16$ \\
\hline $\mathrm{CH}_{4}$ & $\%$ & $69 \pm 3$ & $59-75$ \\
\hline
\end{tabular}

Table 8

Chemical-physical characteristics of the digestate, stability parameters, and production yields during the third trial.

\begin{tabular}{|c|c|c|c|}
\hline Parameter & Units & Average value \pm standard deviation & Min-Max \\
\hline TS & gTS/kg & $61 \pm 4$ & $55-70$ \\
\hline VS & $\mathrm{gVS} / \mathrm{kg}$ & $25 \pm 2$ & $22-32$ \\
\hline $\mathrm{VS} / \mathrm{TS}$ & $\%$ & $41 \pm 2$ & $39-45$ \\
\hline sCOD & $\mathrm{mgO}_{2} / \mathrm{L}$ & $2318 \pm 289$ & $1604-2830$ \\
\hline TKN & $\mathrm{mgN} / \mathrm{L}$ & $2508 \pm 276$ & $2128-2855$ \\
\hline$P_{\text {tot }}$ & $\mathrm{mgP} / \mathrm{L}$ & $277 \pm 119$ & $147-452$ \\
\hline $\mathrm{pH}$ & - & $8.29 \pm 0.05$ & $8.19-8.42$ \\
\hline P. alkalinity & $\mathrm{gCaCO}_{3} / \mathrm{L}$ & $8.55 \pm 0.63$ & $6.75-10.66$ \\
\hline T. alkalinity & $\mathrm{gCaCO}_{3} / \mathrm{L}$ & $12.54 \pm 0.74$ & $10.31-14.79$ \\
\hline VFA & $\mathrm{gCOD} / \mathrm{L}$ & $0.50 \pm 0.24$ & $0.17-1.00$ \\
\hline $\mathrm{N}-\mathrm{NH}_{4}^{+}$ & $\mathrm{mgN} / \mathrm{L}$ & $2357 \pm 300$ & $1800-2914$ \\
\hline SGP & $\mathrm{m}^{3}$ biogas $/ \mathrm{kgVS}$ & $0.59 \pm 0.12$ & $0.45-0.83$ \\
\hline GPR & $\mathrm{m}^{3}$ biogas $/ \mathrm{m}^{3} / \mathrm{d}$ & $0.96 \pm 0.13$ & $0.75-1.26$ \\
\hline $\mathrm{CH}_{4}$ & $\%$ & $66 \pm 2$ & $62-69$ \\
\hline
\end{tabular}

noting (Table 8).

The permeate showed a remarkable reduction in soluble COD and its concentration was maintained below $3 \mathrm{gCOD} / \mathrm{L}$, indicating a significant reduction in dissolved organic substances during the process (Fig. 13). Notice the substantial difference after the adoption of recirculation, in particular in the last period of stationary conditions. It is possible that part of the soluble COD was removed during the stripping process, particularly the volatile organic compounds that were certainly present in the substrate, even if digested.

The control of nitrogen flow in the recirculation line resulted in a marked improvement in the process performance. The average value of SGP for this trial was $0.59 \mathrm{~m}^{3} / \mathrm{kgVS}$. The percentage of methane in the biogas was $65.6 \%$ during the third trial, which had constant HRT and OLR.

Considering the overall main trial, $\mathrm{pH}$ ranged from 8.09 to 8.62. Partial alkalinity ( $\mathrm{pH} 6)$ in the digester effluent was between 6.75 and $11.34 \mathrm{gCaCO}_{3} / \mathrm{L}$, while the total alkalinity $(\mathrm{pH} 4)$ was higher at 10.31-18.04 $\mathrm{gCaCO}_{3} / \mathrm{L}$ (Fig. 14). The higher values were achieved only for short periods and cannot be considered characteristic of the steady state.

During the trial, the trends of the digestate and permeate characteristics were also monitored. Fig. 15 shows that the ratio between VS and TS for the digestate was nearly constant (between 38 and 45\%). On the contrary, the ratio for the feed mixture was more variable (between 42 and 65\%), obviously due to the lack of

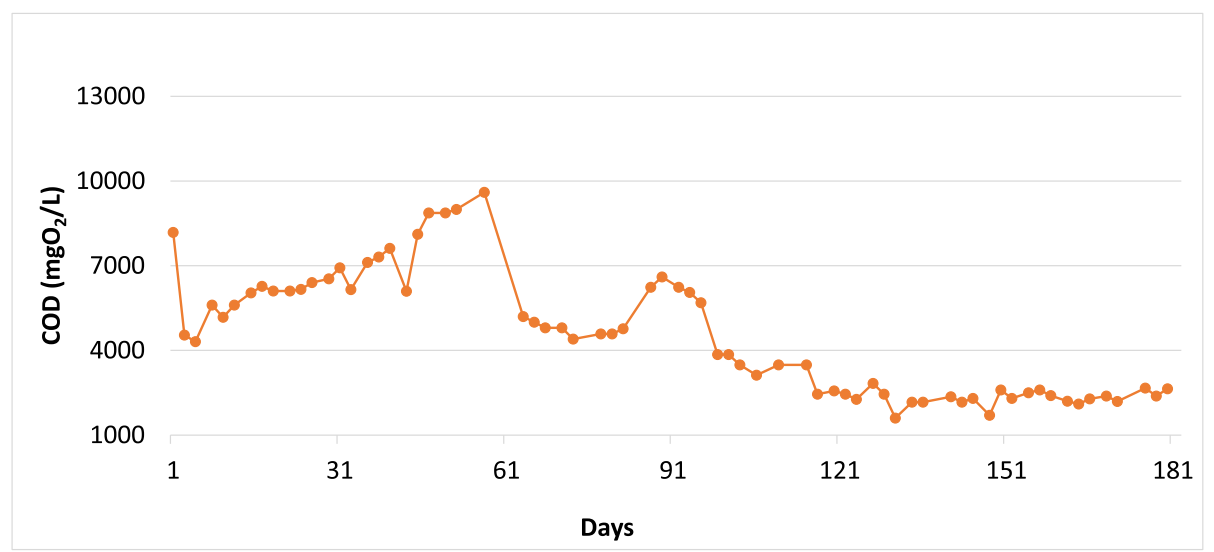

Fig. 13. COD content in the permeate during the trial. 


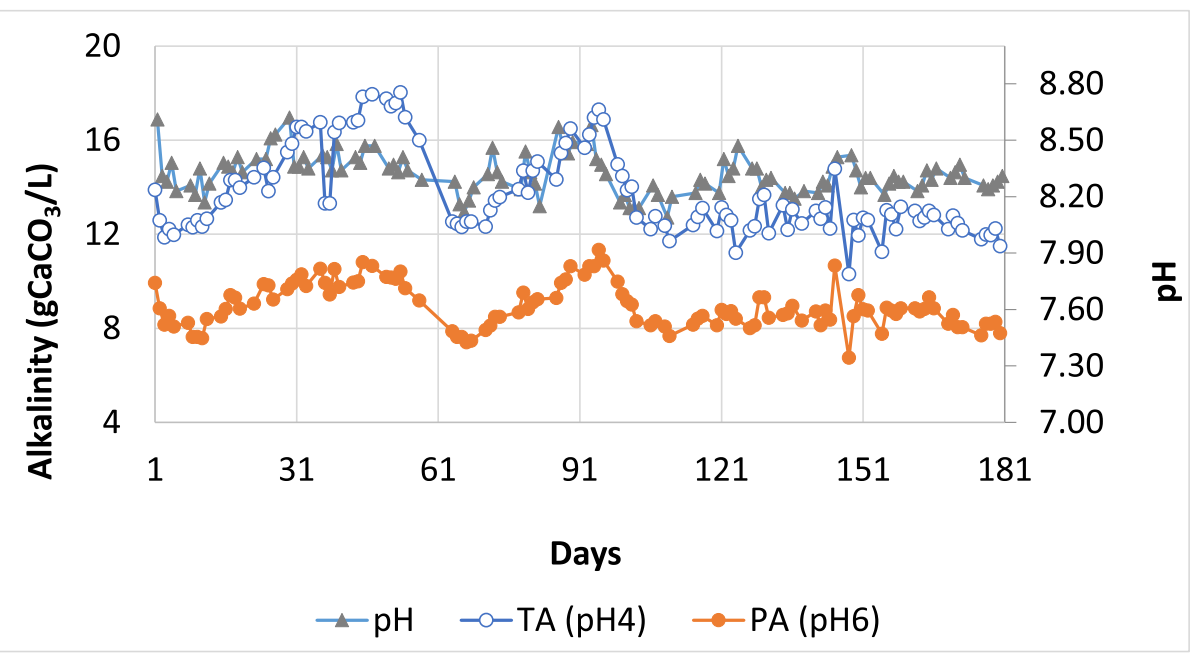

Fig. 14. $\mathrm{pH}$, total $(\mathrm{TA})$ and partial alkalinity $(\mathrm{PA})$ during the trial.

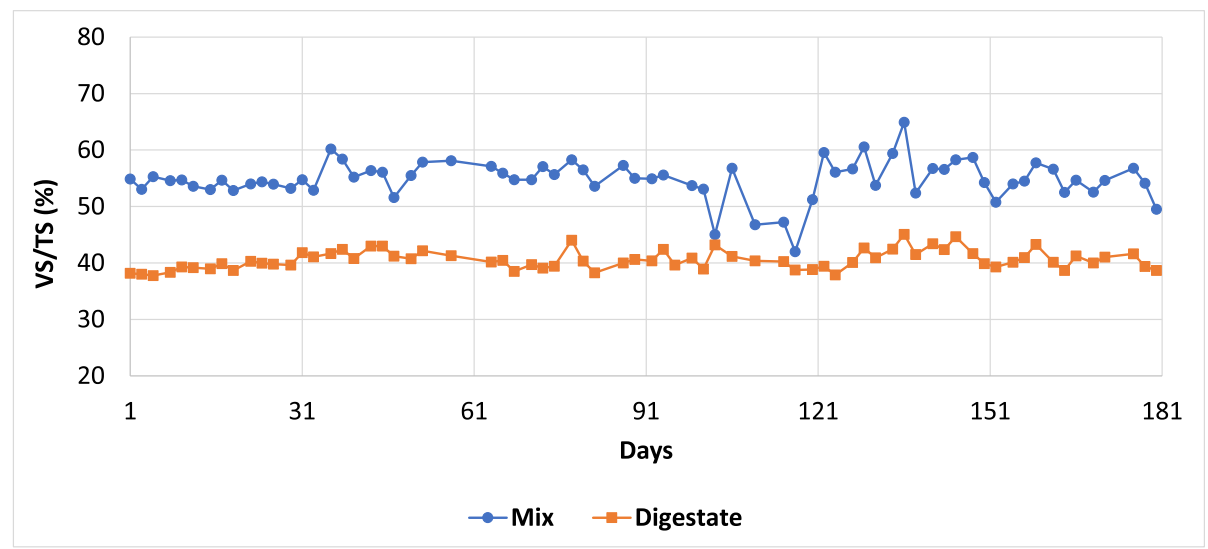

Fig. 15. Ratio between total volatile solids (VS) and total solids (TS) in the feed mix and the digestate during the trial.

homogeneity in the substrate. Under these conditions, the data indicated a reduction of approximately $57 \%$ of VS, which is slightly above the normal values, confirming the stabilization of this kind of substrate (50\%).

\subsection{Ammonium air stripping}

Ammonia removal from the effluent was carried out once a week using the permeate. The $\mathrm{N}-\mathrm{NH}_{4}^{+}$content in the effluent

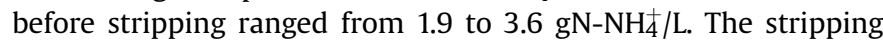
process was conducted as reported in section 2.3.3. Samples were collected from the reactor at each hour during the process and the $\mathrm{N}-\mathrm{NH}_{4}^{+}$concentration was measured (Fig. 16). The process was carried out until the ammonium concentration was below $200 \mathrm{mgN}^{-\mathrm{NH}_{4}^{+}} / \mathrm{L}$. The final permeate with reduced nitrogen content was reused for the preparation of the feed mix after $\mathrm{pH}$ correction.

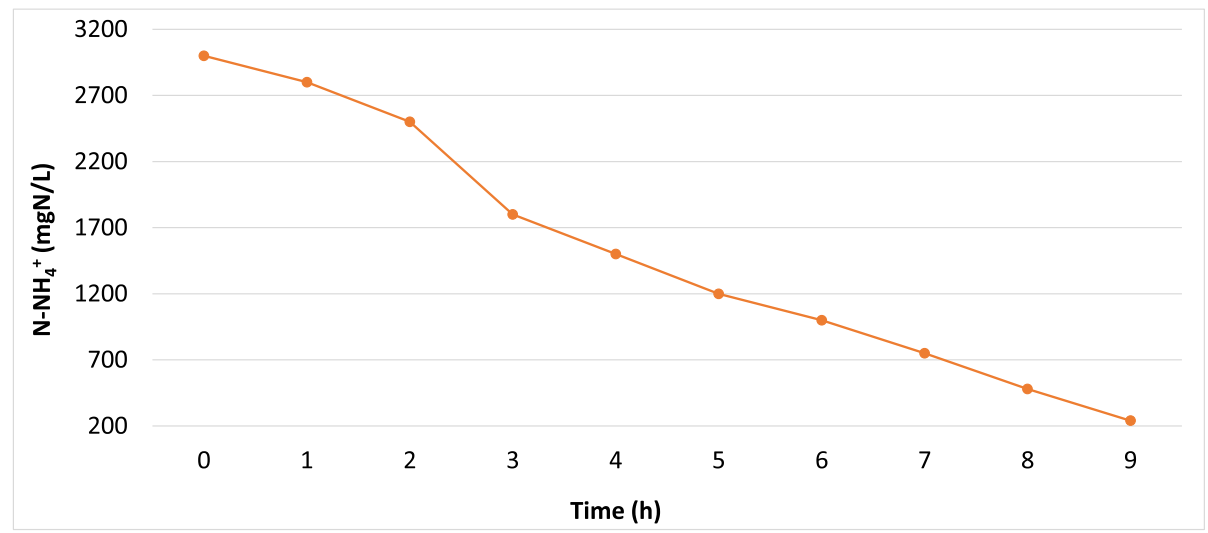

Fig. 16. $\mathrm{N}-\mathrm{NH}_{4}^{+}(\mathrm{mg} / \mathrm{L})$ content during the stripping process. 
Ammonium stripping combined with AnMBR could be a suitable technology for treatment of protein enriched substrates such as livestock effluents; anyway, it is also flexible and could easily be adapted to other agricultural wastes. In the future, this integrated system will be tested using other kinds of substrates such as wine lees, cheese whey, cow manure and grass. In order to reduce the environmental impact, biogas upgrading and digestate stabilization should be studied in further depth.

\section{Conclusions}

Anaerobic digestion of chicken manure was investigated at pilot scale. The present integrated system allowed the anaerobic digestion of this substrate using both single stage and mono-digestion with good results, obtaining a biogas characterized by methane percentages between 60 and 75\%.

It was possible to break down approximately $90 \%$ of the ammonium content by stripping and subsequently recirculating the permeate containing approximately $200 \mathrm{mgN}^{-\mathrm{NH}_{4}^{+}} / \mathrm{L}$. The low nitrogen content, the absence of suspended solids, and a COD content below $3 \mathrm{gO}_{2} / \mathrm{L}$ facilitated further treatment of the effluent and its reuse for irrigation or other purposes.

High COD removal efficiencies were achieved along with stable biogas production. Moreover, an average abatement of $57 \%$ of volatile solids and a digestate production of less than $30 \%$ of the volume fed were observed.

Results obtained during the operating conditions characterized by the adoption of stripping and recirculation of the permeate indicate that the average SGP (0.55 and $0.59 \mathrm{~m}^{3}$ biogas $\left./ \mathrm{kgVS}\right)$ was higher than that found during the first period $\left(0.44 \mathrm{~m}^{3}\right.$ biogas $\left./ \mathrm{kgVS}\right)$, when stripping was not conducted. This showed that the permeate recirculation after ammonia stripping and a correct balance between solid and liquid phase can improve the overall specific production of biogas.

The main advantages of single stage digestion with recirculation after ammonium stripping are environmental sustainability and energy efficiency. In the technology used, an ultrafiltration membrane reactor replaced the traditional digester, thus allowing a reduction in the size of the system and obtaining better performance results. The process showed a satisfactory production of biogas, with appropriate methane percentages, by-products that can be used in agriculture, absence of smell, production of lower quantities of digestate, effluents with lower nitrogen and carbon content requiring potentially simpler and less expensive treatment.

\section{Acknowledgements}

We would like to thank Ca' Foscari University, the waste management company 'Control of Pollution', and Veneto Region for having co-funded this research, which is a beneficiary of the "AGRIBIOFUEL" project funding, POR FESR 2014-2020 Action 1.1.4. (DGR n. 889 del 13/06/2017).

\section{References}

[1] P. Le-Clech, Membrane bioreactors and their uses in wastewater treatments, Appl. Microbiol. Biotechnol. 88 (6) (2010) 1253-1260, https://doi.org/ 10.1007/s00253-010-2885-8.

[2] S. Judd, C. Judd, The MBR Book: Principles and Applications of Membrane Bioreactors in Water and Wastewater Treatment, Elsevier, Oxford, 2011.

[3] L. Dvořák, M. Gómez, J. Dolina, A. Černín, Anaerobic membrane bioreactors - a mini review with emphasis on industrial wastewater treatment: applications, limitations and perspectives, Desalination Water Treat. 57 (41) (2015) 19062-19076, https://doi.org/10.1080/19443994.2015.1100879.

[4] A. Seco, O. Mateo, N. Zamorano-López, P. Sanchis-Perucho, J. Serralta, N. Martí, J. Ferrer, Exploring the limits of anaerobic biodegradability of urban wastewater by AnMBR technology, Environ. Sci.: Water Res. Technol. 4 (11) (2018)
1877-1887, https://doi.org/10.1039/c8ew00313k

[5] S. Judd, The status of industrial and municipal effluent treatment with membrane bioreactor technology, Chem. Eng. J. 305 (2016) 37-45, https:// doi.org/10.1016/j.cej.2015.08.141.

[6] J.J. Chávez-Fuentes, A. Capobianco, J. Barbušová, M. Hutňan, Manure from our agricultural animals: a quantitative and qualitative analysis focused on biogas production, Waste Biomass Valorization 8 (5) (2017) 1749-1757, https:// doi.org/10.1007/s12649-017-9970-5.

[7] H. Nie, H.F. Jacobi, K. Strach, C. Xu, H. Zhou, J. Liebetrau, Mono-fermentation of chicken manure: ammonia inhibition and recirculation of the digestate, Bioresour. Technol. 178 (2015) 238-246, https://doi.org/10.1016/ j.biortech.2014.09.029.

[8] X. Wang, W. Gabauer, Z. Li, M. Ortner, W. Fuchs, Improving exploitation of chicken manure via two-stage anaerobic digestion with an intermediate membrane contactor to extract ammonia, Bioresour. Technol. 268 (2018) 811-814, https://doi.org/10.1016/j.biortech.2018.08.027.

[9] X. Wang, W. Gabauer, Z. Li, M. Ortner, W. Fuchs, Improving exploitation of chicken manure via two-stage anaerobic digestion with an intermediate membrane contactor to extract ammonia, Bioresour. Technol. 268 (2018) 811-814, https://doi.org/10.1016/j.biortech.2018.08.027.

[10] Q. Niu, W. Qiao, H. Qiang, T. Hojo, Y. Li, Mesophilic methane fermentation of chicken manure at a wide range of ammonia concentration: stability, inhibition and recovery, Bioresour. Technol. 137 (2013) 358-367, https://doi.org/ 10.1016/j.biortech.2013.03.080.

[11] I. Angelidaki, B. Ahring, Thermophilic anaerobic digestion of livestock waste: the effect of ammonia, Appl. Microbiol. Biotechnol. 38 (4) (1993), https:// doi.org/10.1007/bf00242955.

[12] K.H. Hansen, I. Angelidaki, B.K. Ahring, Anaerobic digestion of swine manure: inhibition by ammonia, Water Res. 32 (1) (1998) 5-12, https://doi.org/ 10.1016/s0043-1354(97)00201-7.

[13] N. Krakat, B. Demirel, R. Anjum, D. Dietz, Methods of ammonia removal in anaerobic digestion: a review, Water Sci. Technol. 76 (8) (2017) 1925-1938, https://doi.org/10.2166/wst.2017.406.

[14] W. Fuchs, X. Wang, W. Gabauer, M. Ortner, Z. Li, Tackling ammonia inhibition for efficient biogas production from chicken manure: status and technical trends in Europe and China, Renew. Sustain. Energy Rev. 97 (2018) 186-199, https://doi.org/10.1016/j.rser.2018.08.038.

[15] G. Bujoczek, J. Oleszkiewicz, R. Sparling, S. Cenkowski, High solid anaerobic digestion of chicken manure, J. Agric. Eng. Res. 76 (1) (2000) 51-60, https:// doi.org/10.1006/jaer.2000.0529.

[16] A. Jaxybayeva, C. Yangin-Gomec, Z. Cetecioglu, E.G. Ozbayram, F. Yilmaz O. Ince, Bioenergy production from diluted poultry manure and microbial consortium inside anaerobic sludge bed reactor at sub-mesophilic conditions, J. Environ. Sci. Health, Part B 49 (10) (2014) 775-785, https://doi.org/10.1080/ 03601234.2014.929911.

[17] C. Li, S. Strömberg, G. Liu, I.A. Nges, J. Liu, Assessment of regional biomass as co-substrate in the anaerobic digestion of chicken manure: impact of codigestion with chicken processing waste, seagrass and miscanthus, Biochem. Eng. J. 118 (2017) 1-10, https://doi.org/10.1016/j.bej.2016.11.008.

[18] M. Altinbas, O.A. Cicek, Anaerobic co-digestion of chicken and cattle manures: free ammonia inhibition, Energy Sources, Part A Recovery, Util. Environ. Eff. 41 (9) (2018) 1097-1109, https://doi.org/10.1080/15567036.2018.1539143.

[19] X. Wang, W. Gabauer, Z. Li, M. Ortner, W. Fuchs, Improving exploitation of chicken manure via two-stage anaerobic digestion with an intermediate membrane contactor to extract ammonia, Bioresour. Technol. 268 (2018) 811-814, https://doi.org/10.1016/j.biortech.2018.08.027.

[20] J. Park, J. Yoon, G. Kumar, Y. Jin, S. Kim, Effects of acclimation and pH on ammonia inhibition for mesophilic methanogenic microflora, Waste Manag. 80 (2018) 218-223, https://doi.org/10.1016/j.wasman.2018.09.016.

[21] G. Wang, X. Xu, L. Zhou, C. Wang, F. Yang, A pilot-scale study on the start-up of partial nitrification-anammox process for anaerobic sludge digester liquor treatment, Bioresour. Technol. 241 (2017) 181-189, https://doi.org/10.1016/ j.biortech.2017.02.125.

[22] C. Pedizzi, J.M. Lema, M. Carballa, A combination of ammonia stripping and low temperature thermal pre-treatment improves anaerobic post-digestion of the supernatant from organic fraction of municipal solid waste treatment, Waste Manag. 78 (2018) 271-278, https://doi.org/10.1016/ j.wasman.2018.05.051.

[23] K. Orner, C. Cools, M. Balaguer-Barbosa, N. Zalivina, J.R. Mihelcic, G. Chen, J.A. Cunningham, Energy recovery and nitrogen management from struvite precipitation effluent via microbial fuel cells, J. Environ. Eng. 145 (3) (2019) 04018145, https://doi.org/10.1061/(asce)ee.1943-7870.0001500.

[24] M. Waqas, T. Almeelbi, A. Nizami, Resource recovery of food waste through continuous thermophilic in-vessel composting, Environ. Sci. Pollut. Control Ser. 25 (6) (2017) 5212-5222, https://doi.org/10.1007/s11356-017-9358-x.

[25] APHA, Standard Methods for the Examination of Water and Wastewater twentieth ed., American Public Health Association, Washington, DC, 1998.

[26] RiducaReflui Project, Nitrate from problem to resource, state of art and chances. Reduction of pollutant load deriving from livestock effluents in draining basin of Venetian lagoon, Veneto Reg. 4 (2008) 66-128. Chapter 4, riducareflui.venetoagricoltura.org/dmdocuments/report-finale.pdf (Italian language). 